\title{
ИССЛЕДОВАНИЕ ТЕМПЕРАТУРНОГО ПОЛЯ В СЛОИСТОМ ПЛАСТЕ
}

\author{
Исламов Денис Фавилович', \\ islamovden@rambler.ru
}

\author{
Садретдинов Александр Александрович', \\ aleex.aa@gmail.com. \\ ' Башкирский государственный университет, \\ Россия, 450074, г. Уфа, ул. Заки Валиди, 32.
}

\begin{abstract}
Актуальность. В последнее время усиливается интерес к количественной интерпретации температурных измерений в скважине. Целями количественной интерпретации становятся индивидуальные дебиты жидкости из отдельных пластов, пластовое давление в отдельных пластах, дебит заколонного перетока, гидродинамические параметры пластов, характер изменения проницаемости пласта в прискважинной зоне. В качестве исходных данных для переходных процессов используются нестационарные поля давления и температуры в скважине, а для квазистационарных условий - распределение температуры по глубине. Особый интерес представляет определение дебитов притока из отдельных пластов и параметров прискважинной зоны пластов.

Цель: оценить, насколько допущение об однородности пласта влияет на наблюдаемую температуру для некоторых сценариев работы скважины.

Методы. Разработана и исследована численная модель, дискретизация осуществлена методом контрольных объемов, используется метод переменных направлений. Корректность численного решения проверена путем сравнения с известными аналитическими решениями.

Результаты. Исследована задача о нестационарном температурном поле в слоистом пласте. Среднее отклонение решения для случая закачки может достигать 20 \% и более, величина зависит от толщины (общего количества) пропластков. Среднее отклонение решения для случая закачки достигает максимум через 6-10 часов и далее медленно уменьшается со временем. Для случая добычи величина отклонения может достигать 100 \%, максимум достигается в начале восстановления. Далее отклонение снижается, достигая через 24 часа величины порядка 40 \% от первоначального отклонения. Задаваясь допустимой погрешностью решения в 10 \% при моделировании восстановления в слоистых коллекторах, необходимо учитывать слоистость при ее величинах выше 15-25\% в зависимости от сценария работы скважины.
\end{abstract}

\section{Ключевые слова:}

Геофизика, термометрия, скважина, пласт, проницаемость, численное решение.

\section{Введение}

Как показывает практика геофизических исследований скважин (ГИС) и исследований керна, не бывает совершенно однородных пластовколлекторов [1-3]. Существует прямая зависимость влияния геологической неоднородности на продуктивность и конечную величину отдачи залежи. Поэтому развитие методов изучения геологической неоднородности горных пород относительно их фильтрационно-емкостных свойств и ее учет при подсчете запасов и разработке залежей остаются весьма актуальными направлениями.

Одним из перспективных и не до конца изученных методов изучения пластов является термометрия [4-10]. Потенциальным преимуществом использования температурных данных является значительно меньшая скорость и глубина распространения температурных возмущений, что позволяет получить информацию о свойствах внутрипластового пространства.

В задачах количественной интерпретации результатов ГИС обычно считают пласт однородным, хотя на самом деле он может быть существенно слоистым [11-19]. Цель данной работы - оценить, насколько допущение об однородности пласта влияет на наблюдаемую температуру для некоторых сценариев работы скважины.
Данная работа построена на изучении закономерностей пространственно-временного распределения температурного поля в слоистом пласте на основе численного моделирования однофазной фильтрации жидкости в пористой среде с учетом конвективного и кондуктивного теплопереноса, баротермического эффекта и теплообмена с окружающими пласт непроницаемыми горными породами.

Разработанная модель позволяет моделировать случаи закачки, отбора и восстановления температуры в остановленных скважинах. Изменение температуры после остановки происходит только за счет одномерного вертикального теплопереноса за счет теплопроводности среды. Температурные исследования в остановленных скважинах активно используются на практике с целью определения интервалов поглощения и заколонных движений жидкости.

\section{Математическая модель}

Изменение температуры в пласте описывается уравнением (1) [4, 14]:

$$
\begin{gathered}
C_{r e s}(z) \frac{\partial T}{\partial t}+C_{f}(z) v(r, z) \frac{\partial T}{\partial r}= \\
=\frac{1}{r} \frac{\partial}{\partial r}\left(\lambda(r, z) r \frac{\partial T}{\partial r}\right)+\frac{\partial}{\partial z}\left(\lambda(r, z) \frac{\partial T}{\partial z}\right)+\Phi(r, z),
\end{gathered}
$$

где $\Phi(r, z)$ - источниковое слагаемое (2). 


$$
\Phi(r, z)=-C_{f}(z) v(r, z) \varepsilon \frac{\partial p}{\partial r}+\varphi C_{f}(z) \eta \frac{\partial p}{\partial t} .
$$

Здесь $C_{\text {res }}, C_{f}$ - объемные теплоемкости пласта и

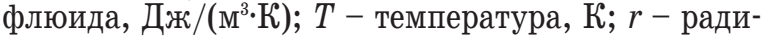
альная координата, расстояние от оси скважины, $\mathrm{m} ; z$ - вертикальная координата, м; $t$ - время, с; $v-$ скорость фильтрации флюида (по линейному закону Дарси), м/с; $\lambda$ - теплопроводность, Вт $/(\mathrm{s} \cdot К) ; \varepsilon$, $\eta$ - коэффициент Джоуля-Томсона и адиабатический коэффициент для флюида, К/Па; $\varphi$ - пористость, д. ед.; $p$ - давление в пласте, Па.

Граничное условие на стенке скважины (т. е. при $r=r_{w}$ ) описывается системой (3).

$$
\begin{cases}\left.\frac{\partial T}{\partial r}\right|_{r=r_{w}}=0, & \left.v\right|_{r=r_{w}} \leq 0 \\ \left.T\right|_{r=r_{w}}=T_{i n j}, & \left.v\right|_{r=r_{w}}>0 .\end{cases}
$$

Поле давления по сравнению с полем температуры устанавливается мгновенно, как в жестком пласте с бесконечной пьезопроводностью, и описывается формулой (4) [20]:

$$
p(r, z)=p_{w}(t)+\frac{Q(z)}{2 \pi \sigma(z)} \ln \left(\frac{r}{r_{w}}\right),
$$

где $p_{w}$ - давление в скважине, Па; $Q$ - дебит пропластка, $\mathrm{m}^{3} /$ сут; $\sigma$ - гидропроводность, $\mathrm{M}^{3} /($ Па с).

Задача (1)-(3) решалась численно, методом прогонки. Дискретизация уравнений осуществлена методом контрольного объема. Корректность численного решения проверена путем сравнения с известными аналитическими решениями [14]. Для проверки корректности численного расчета радиальной теплопроводности рассматривается задача об остывании нагретого цилиндра в бесконечной среде с постоянной температуропроводностью [21]. Для проверки корректности численного расчета вертикальной теплопроводности использовано известное решение задачи об остывании бесконечной нагретой плиты [21]. Корректность расчета изменения температуры за счет баротермического эффекта проверена на известном аналитическом решении Э.Б. Чекалюка задачи о температуре пласта при фильтрации жидкости в стационарном поле давления [4]. Результаты численного моделирования и расчета по аналитической модели Э.Б. Чекалюка отличаются не более чем на $0,1 \%$.

Разработанная математическая модель позволяет моделировать температурное поле в пласте с любой неоднородностью. Но для исследования и для того, чтобы доказать, что учет неоднородности важен, рассматривается частный случай неоднородности, представленной чередованием проницаемых и непроницаемых пропластков.

В рамках исследования расчеты осуществлялись для двух конфигураций пласта. Пласт толщиной 10 м разделен на пропластки по следующему принципу (рис. 1, 2):

1) соотношение проницаемых и непроницаемых пропластков 5:5 (10 пропластков: 5 проницаемых и 5 непроницаемых);

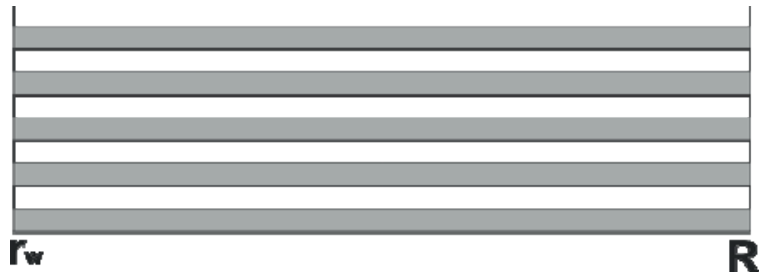

Рис. 1. Моделируелый пласт 5:5 (Бельл - проницаелые пропластки, Серым - непроницаемые пропластки)

Fig. 1. Simulated reservoir 5:5 (White - permeable layers, Grayimpermeable layers)

2) соотношение проницаемых и непроницаемых пропластков 10:10 (20 пропластков: 10 проницаемых и 10 непроницаемых).

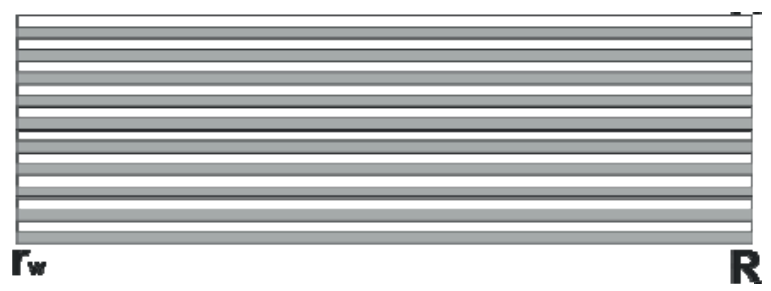

Рис. 2. Моделируемый пласт 10:10 (Бельм - проницаемые пропластки, Серыл-непроницаемые пропластки)

Fig. 2. Simulated reservoir 10:10 (White-permeable layers, Grayimpermeable layers)

Проницаемые и непроницаемые пропластки чередуются. Они считаются гидродинамически изолированными (т. е. перетоков между пропластками нет), но термически контактирующими.

\section{Результаты моделирования}

Для каждой конфигурации пласта смоделировано два случая восстановления профиля температуры после кратковременной работы скважины:

1) закачка (начальная температура пласта $20{ }^{\circ} \mathrm{C}$, температура закачиваемой жидкости $\left.10{ }^{\circ} \mathrm{C}\right)$;

2) добыча (отбор жидкости из пласта).

\section{1. Закачка}

Смоделирован случай восстановления профиля температуры после кратковременной закачки с постоянным расходом $100 \mathrm{~m}^{3} /$ сут. Закачка длилась 5 часов. Сравнивались профили температуры через 20 часов после прекращения закачки.

Суммарная толщина непроницаемых пропластков варьируется от 1 до $40 \%$ в общей толщине пласта. Проницаемости проницаемых пропластков 100 мд.

На рис. 3 представлен пример профилей температур для однородного пласта и для пласта 5:5 с долей непроницаемых пропластков $40 \%$. Как видно из рис. 3, температура напротив непроницаемых пропластков восстанавливается значительно быстрее, нежели напротив проницаемых. Данный факт подтверждается наличием положительных пиков температуры напротив непроницаемых пропластков.

На рис. 4 представлен пример профилей температур для однородного пласта и для пласта 10:10 с долей непроницаемых пропластков 40 \% . 


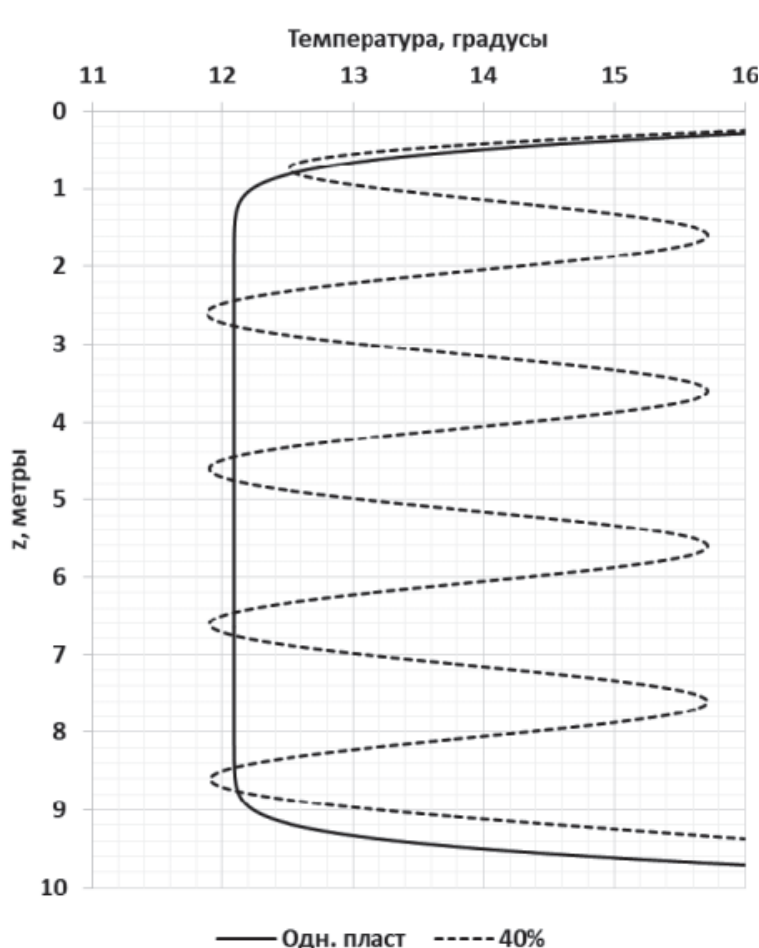

Рис. 3. Профили температур через 20 часов после прекращения закачки

Fig. 3. Temperature profiles in 20 hours after the injection stop

На рис. 5 представлена зависимость отклонения решения для неоднородного пласта от доли непроницаемых пропластков. Отклонение - это среднее значение отклонений результатов для однородного и неоднородного пласта. Формула для расчета (5).

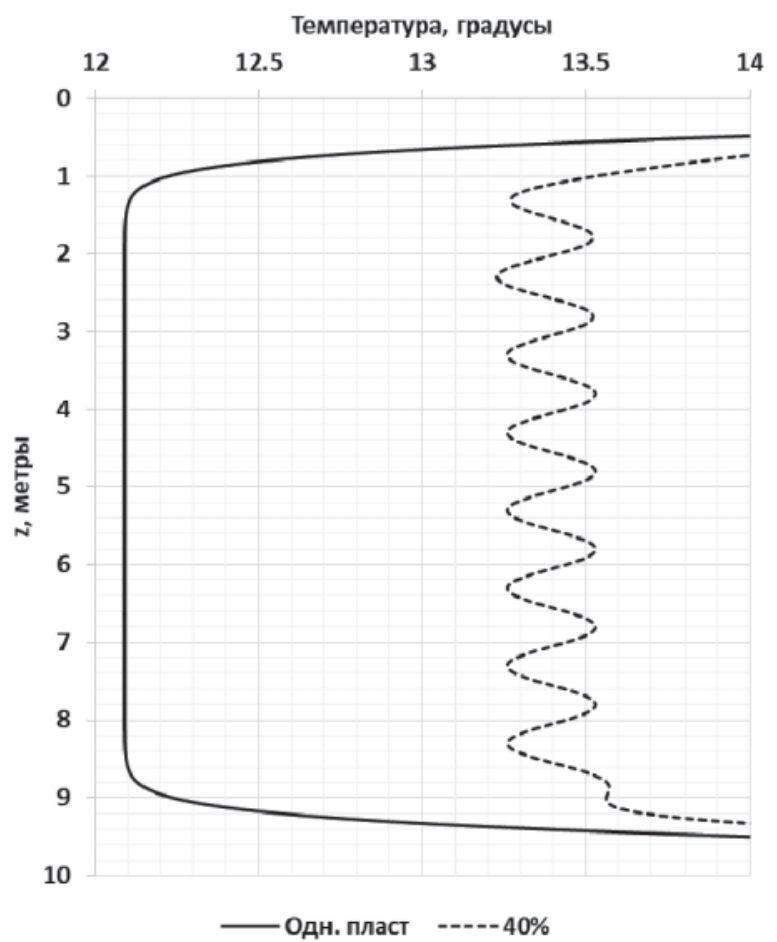

Рис. 4. Профили температур через 20 часов после прекращения закачки

Fig. 4. Temperature profiles in 20 hours after the injection stop

$$
\Delta=\frac{\sum_{i=1}^{n}\left|\frac{T_{\text {одн, } i}-T_{\text {неодн }, i}}{T_{\text {пл }}-T_{\text {сак }}} \cdot 100 \%\right|}{n},
$$

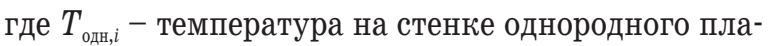
ста; $T_{\text {неодн }, ~}$ - температура на стенке неоднородного

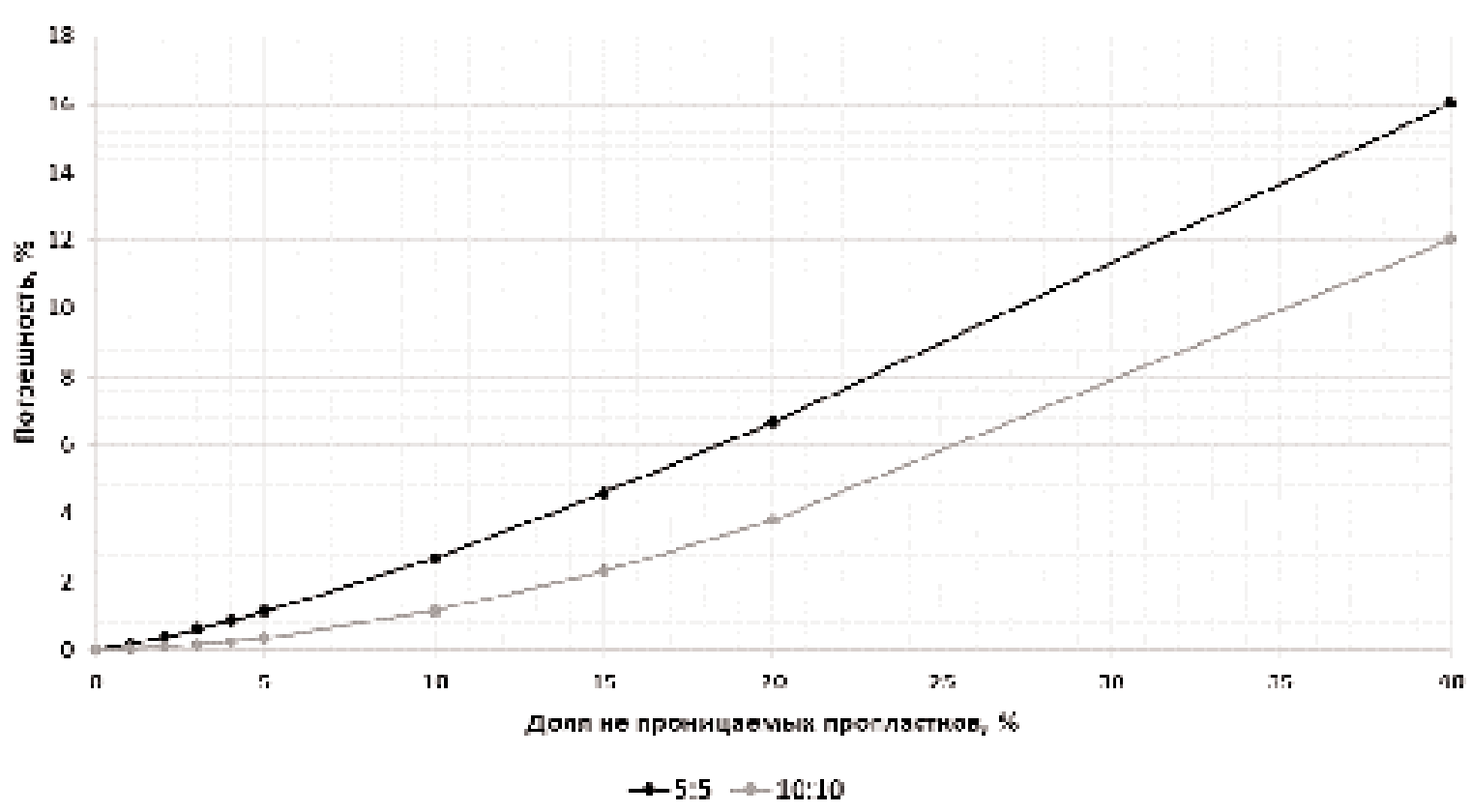

Pис. 5. Графики средних значений отклонений профилей температуры через 20 часов после прекращения закачки

Fig. 5. Graphs of the average deviations in the temperature profiles in 20 hours after the injection stop 
пласта; $T_{\text {пл }}$ - начальная пластовая температура; $T_{\text {зак }}$ - температура закачиваемой в пласт жидкости; $n$ - количество точек в температурном профиле; $i-$ индекс точки в профиле.

Доля непроницаемых пропластков - процент содержания непроницаемых пропластков в общей толще пласта.
Из рис. 5 видно, что чем больше толщина непроницаемых пропластков, тем больше отклонение. Но оно уменьшается при увеличении общего количества пропластков. При доле непроницаемых пропластков до $5 \%$ значения погрешностей для пластов 5:5 и 10:10 незначительно отличаются друг друга.

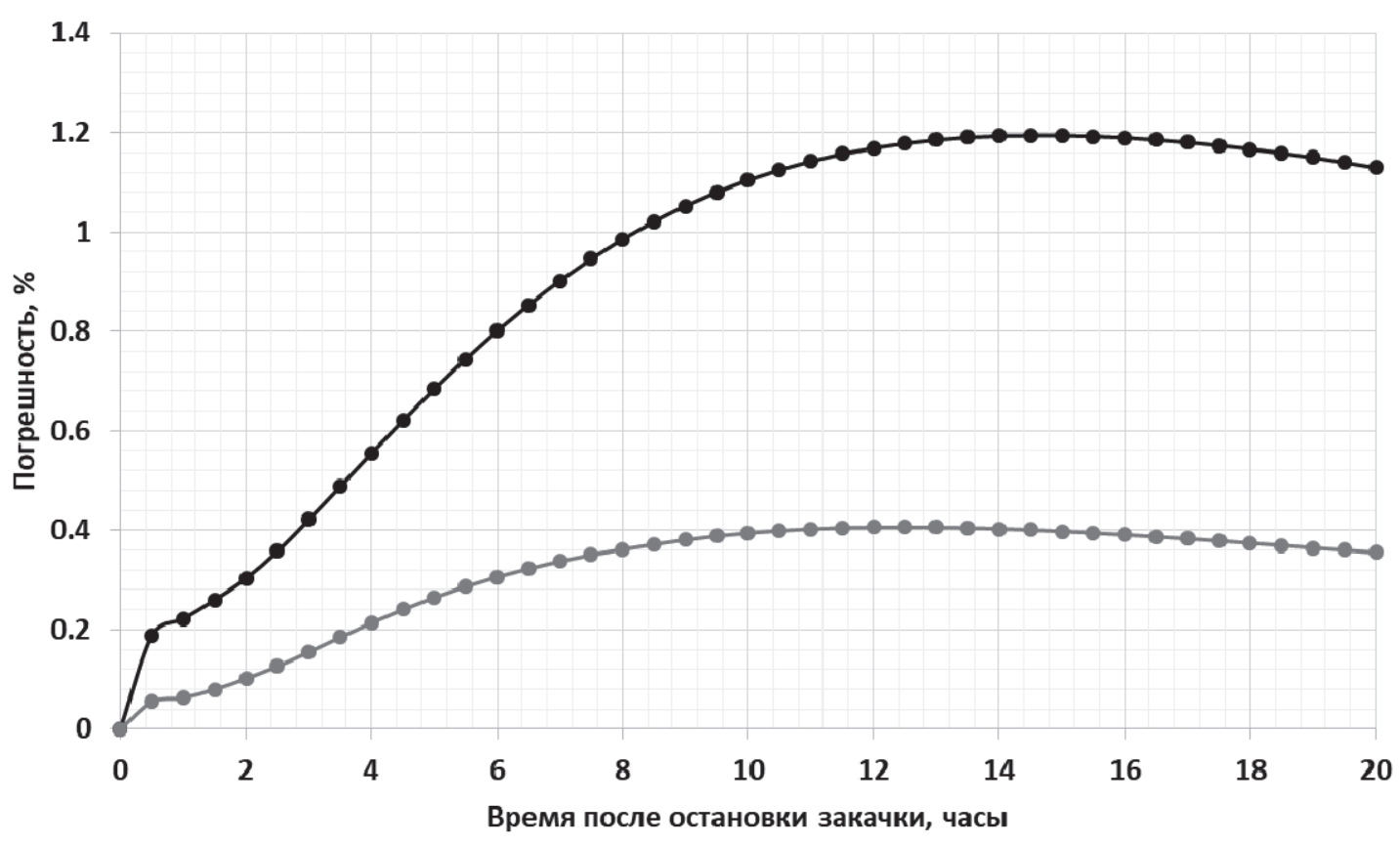

$\rightarrow 5: 5 \rightarrow 10: 10$

Puc. 6. Изменение отклонения в зависимости от времени для доли непроницаемых пропластков $5 \%$

Fig. 6. Change of deviation depending on the time for the proportion of impervious layers of $5 \%$

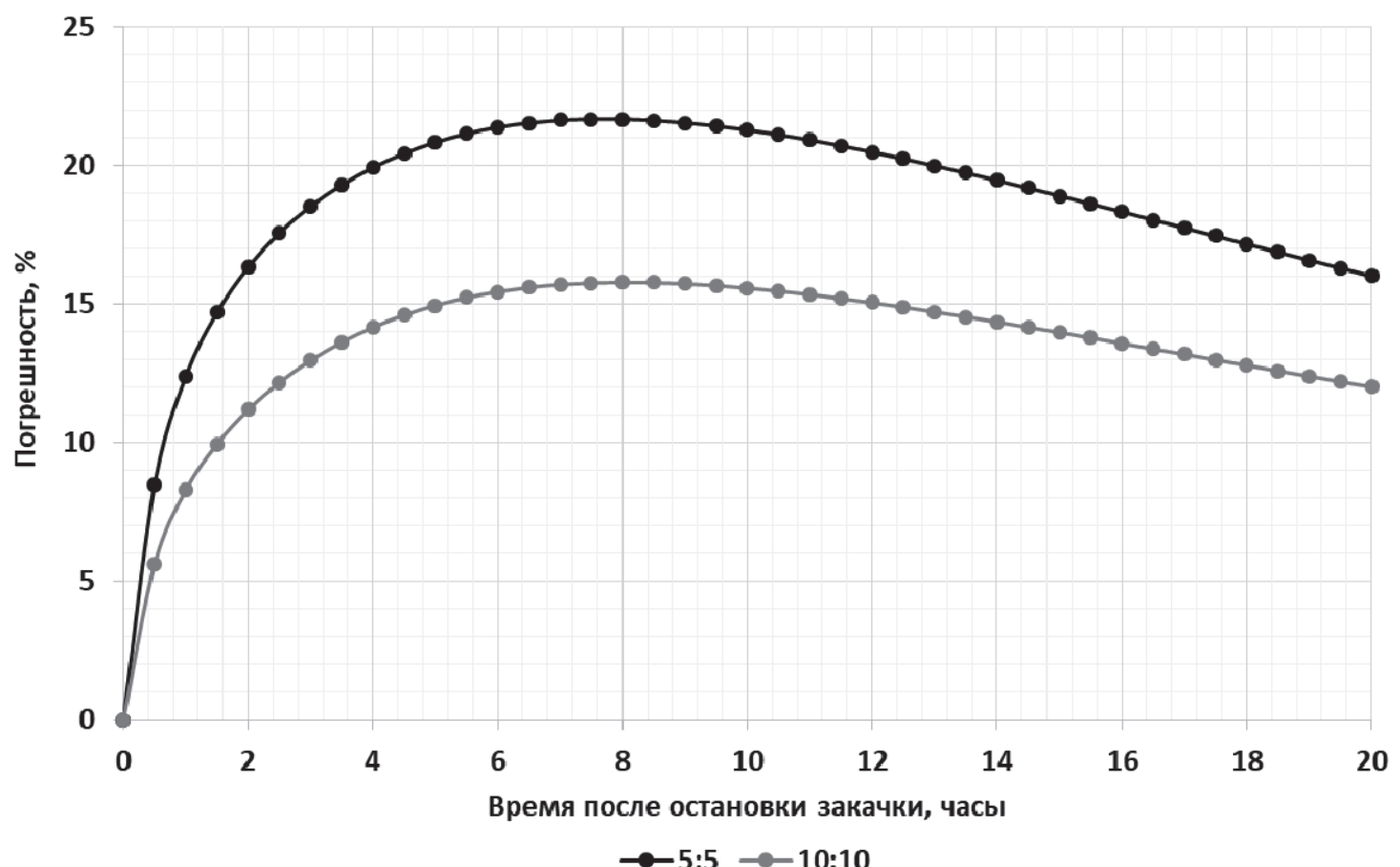

Рис. 7. Изленение отклонения в зависимости от времени для доли непроницаемых пропластков $40 \%$

Fig. 7. Change of deviation depending on the time for the proportion of impervious layers of $40 \%$ 
Еще можно заметить, что вставки непроницаемых пропластков с долей до 15 \% приводят к отклонениям до $5 \%$.

Если построить графики изменения отклонений после прекращения закачки в зависимости от времени (рис. 6,7 ), то видно, что отклонение растет до определенного момента времени, а после идет на спад.

\section{2. Добыча}

Смоделирован случай восстановления профиля температуры после кратковременного отбора жидкости из пласта при постоянной депрессии 50 атм. Время добычи 24 часа. Сравнивались профили температуры через 24 часа после прекращения отбора жидкости. $10 \mathrm{~mL}$

Проницаемости проницаемых пропластков

На рис. 8 представлен пример профилей температур для однородного пласта и для пласта $5: 5$ с долями непроницаемых пропластков 50 и $90 \%$. В данном случает температура напротив непроницаемых пропластков так же, как в случае закачки, восстанавливается быстрее, чем температура напротив проницаемых пропластков. Данный факт проявляется отрицательной аномалией температуры напротив непроницаемых участков. Также из рис. 8 видно, что чем больше доля непроницаемых пропластков, тем медленнее восстанавливается температура пласта.

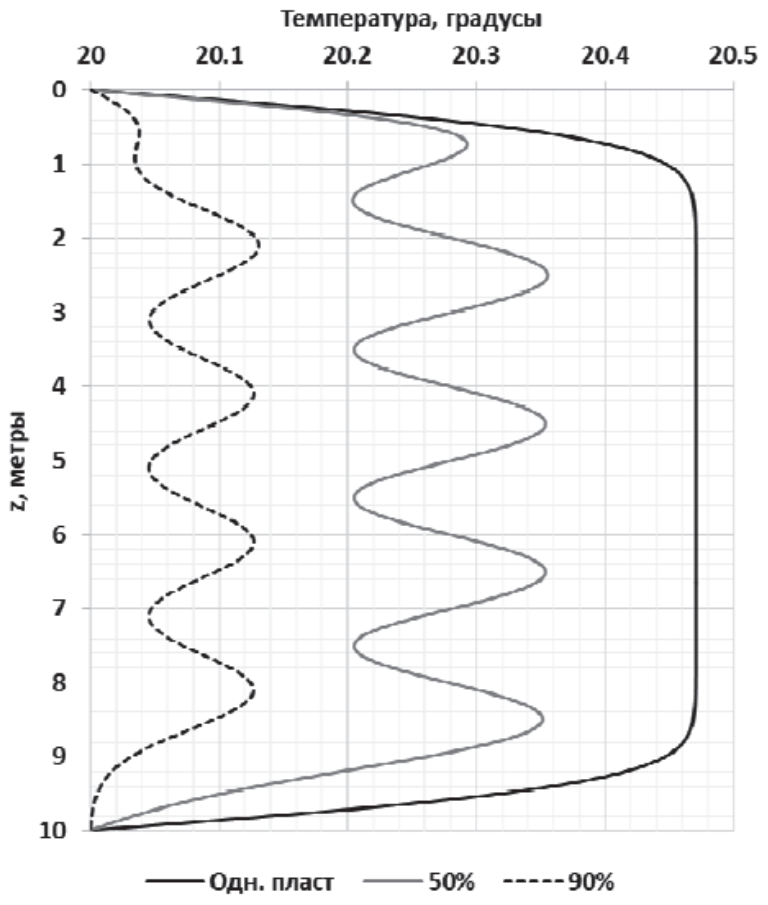

Рис. 8. Профили температур через 24 часа после прекращения отбора

Fig. 8. Temperature profiles in 24 hours after the production stop

На рис. 9 представлен пример профилей температур для однородного пласта и для пласта 10:10 с долями непроницаемых пропластков 50 и $90 \%$.

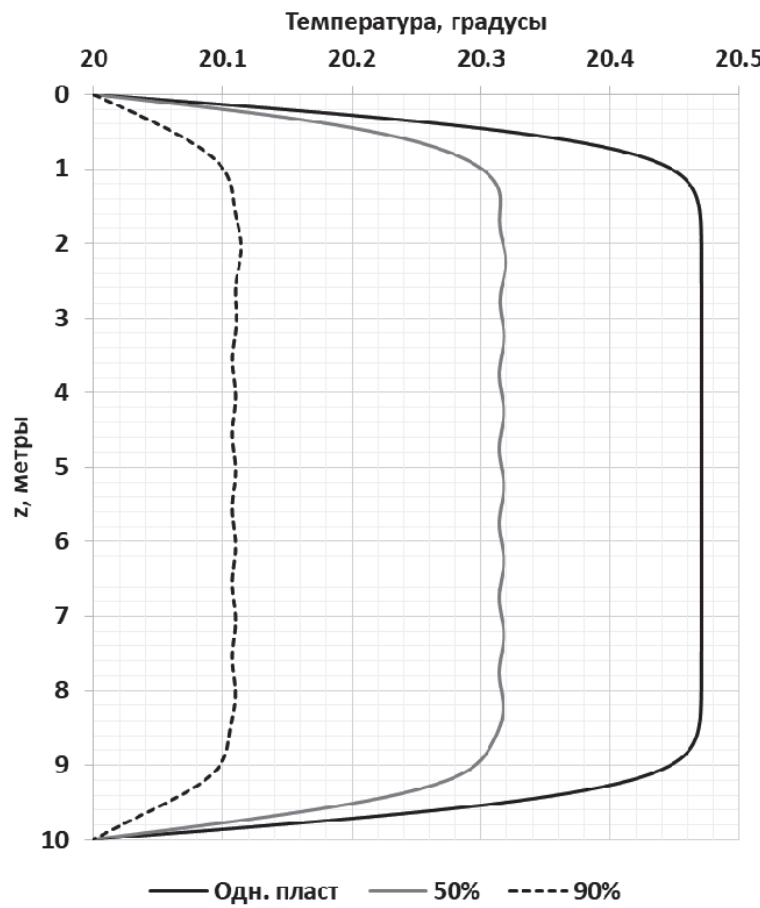

Рис. 9. Профили температур через 24 часа после прекращения отбора

Fig. 9. Temperature profiles in 24 hours after the production stop

На рис. 10 представлена зависимость отклонения от доли непроницаемых пропластков. Отклонения рассчитывались по формуле (6):

$$
\Delta=\frac{\sum_{i=1}^{n}\left|\frac{T_{\text {одн }, i}-T_{\text {неодн }, i}}{(\varepsilon \Delta P)_{\text {одн }}} \cdot 100 \%\right|}{n},
$$

где $T_{\text {одн, }}$ - температура на стенке однородного пласта; $T_{\text {недн, }}$ - температура на стенке неоднородного пласта; $(\varepsilon \Delta P)_{\text {одн }}$ - разогрев в момент остановки отбора для однородного пласта; $n$ - количество точек в температурном профиле; $i$ - индекс точки в профиле.

Из рис. 10 видно, что чем больше толщина непроницаемых пропластков, тем больше отклонение. Оно незначительно уменьшается при увеличении общего количества пропластков.

Если, аналогично случаю закачки, построить графики изменения погрешностей после прекращения отбора в зависимости от времени (рис. 11, $12)$, то видно, что погрешность падает со временем.

\section{Выводы}

1. Среднее отклонение решения для случая закачки может достигать $20 \%$ и более, величина зависит от толщины (общего количества) пропластков.

2. Среднее отклонение решения для случая закачки достигает максимум через $6-10$ часов и далее медленно уменьшается со временем.

3. Для случая добычи величина отклонения может достигать $100 \%$, максимум достигается в начале восстановления. Далее отклонение сни- 


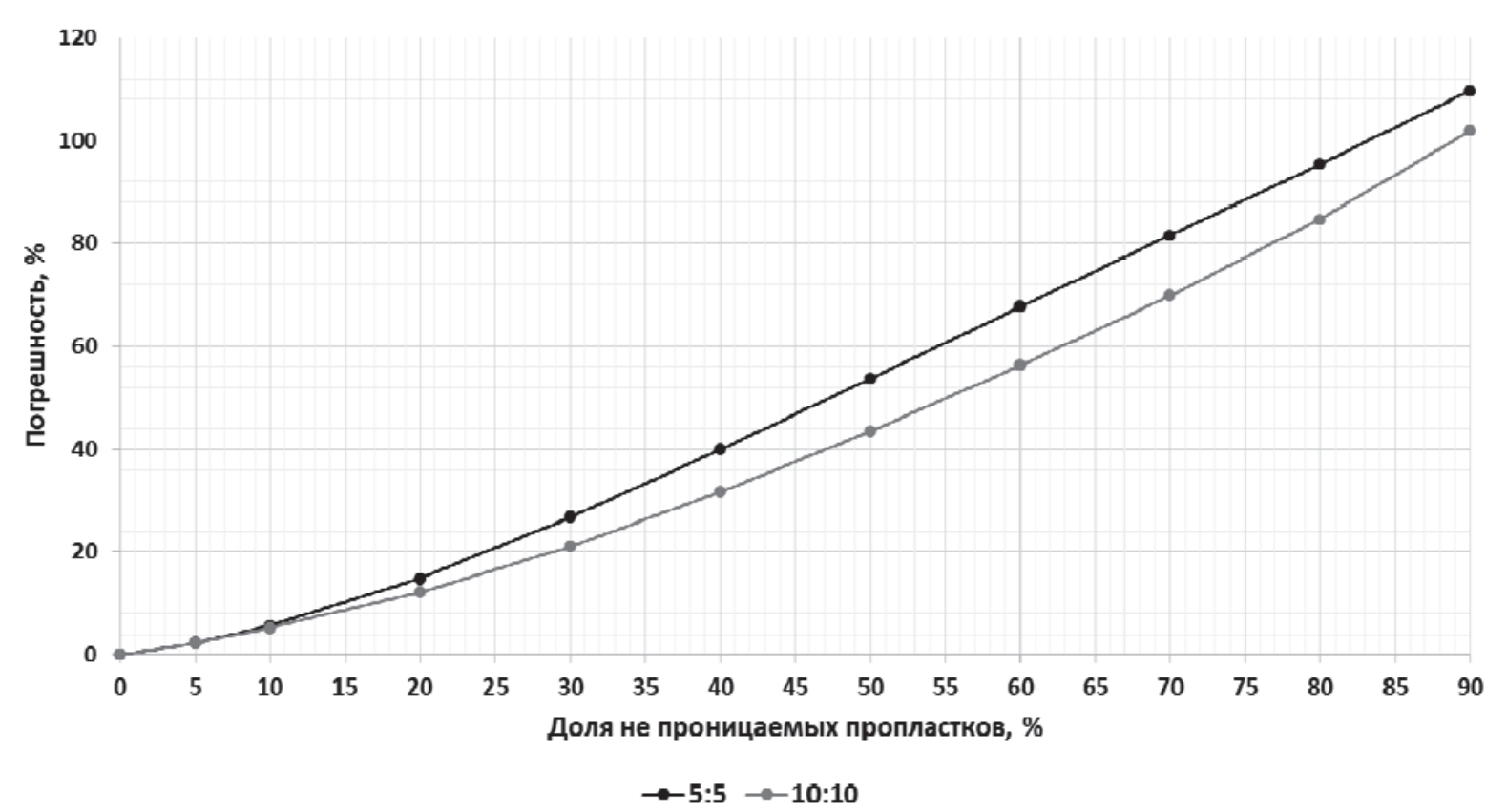

Рис. 10. Графики средних значений отклонений профилей телпературы через 24 часов после прекращения отбора жидкости

Fig. 10. Graphs of the average deviations in the temperature profiles in 24 hours after the production stop

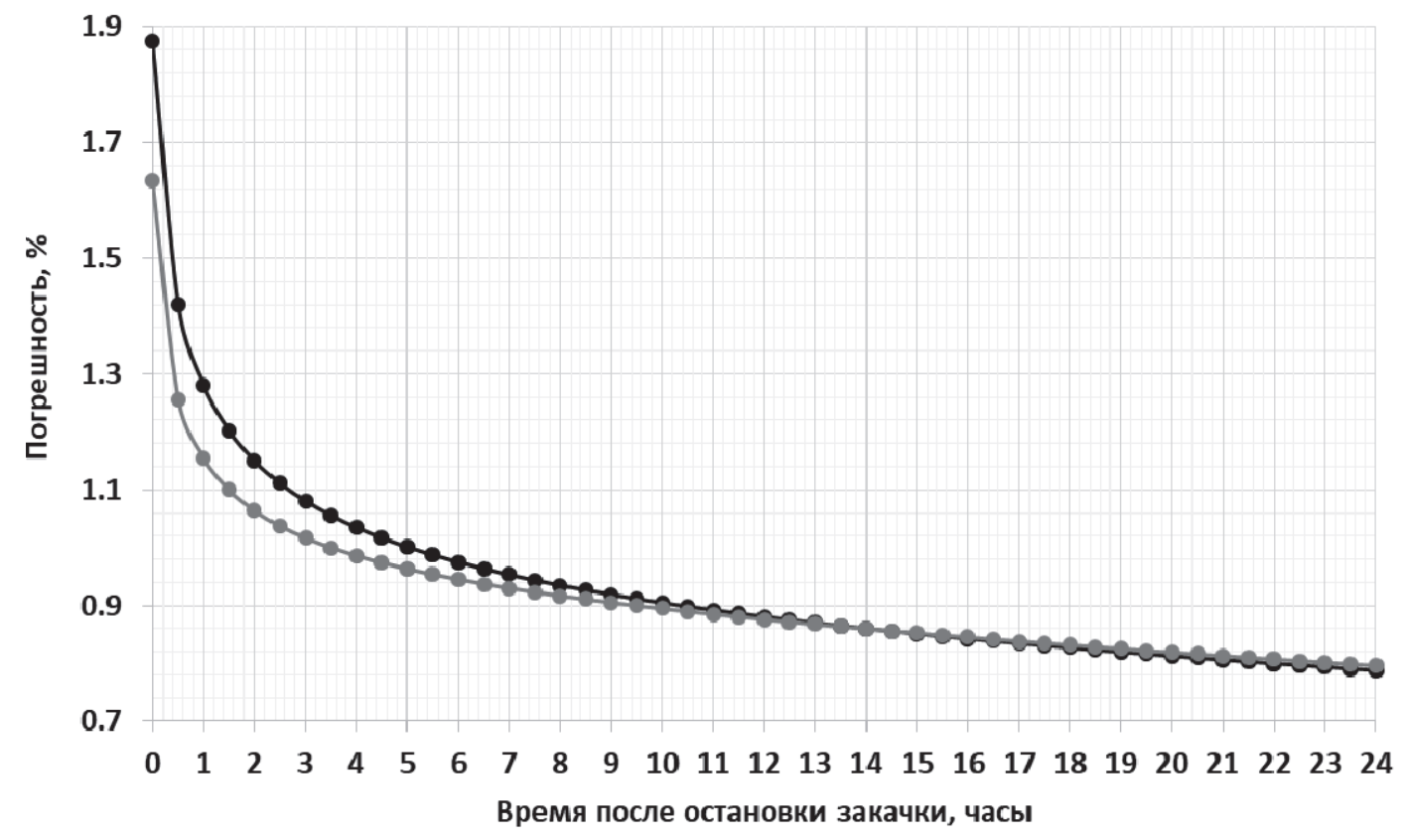

$\rightarrow-5: 5 \rightarrow-10: 10$

Рис. 11. Изменение погрешности в зависимости от времени для доли непроницаемых пропластков $5 \%$

Fig. 11. Change of deviation depending on the time for the proportion of impervious layers of $5 \%$

жается, достигая через 24 часа величины порядка $40 \%$ от первоначального отклонения.

4. Задаваясь допустимой погрешностью решения в $10 \%$ при моделировании восстановления в слоистых коллекторах, необходимо учиты- вать слоистость при ее величинах выше 15-25\% в зависимости от сценария работы скважины.

Работа выполнена при финансовой поддержке РФФИ (проект № 16-35-00275 мол_а, проект № 16-29-15130 офи_м). 


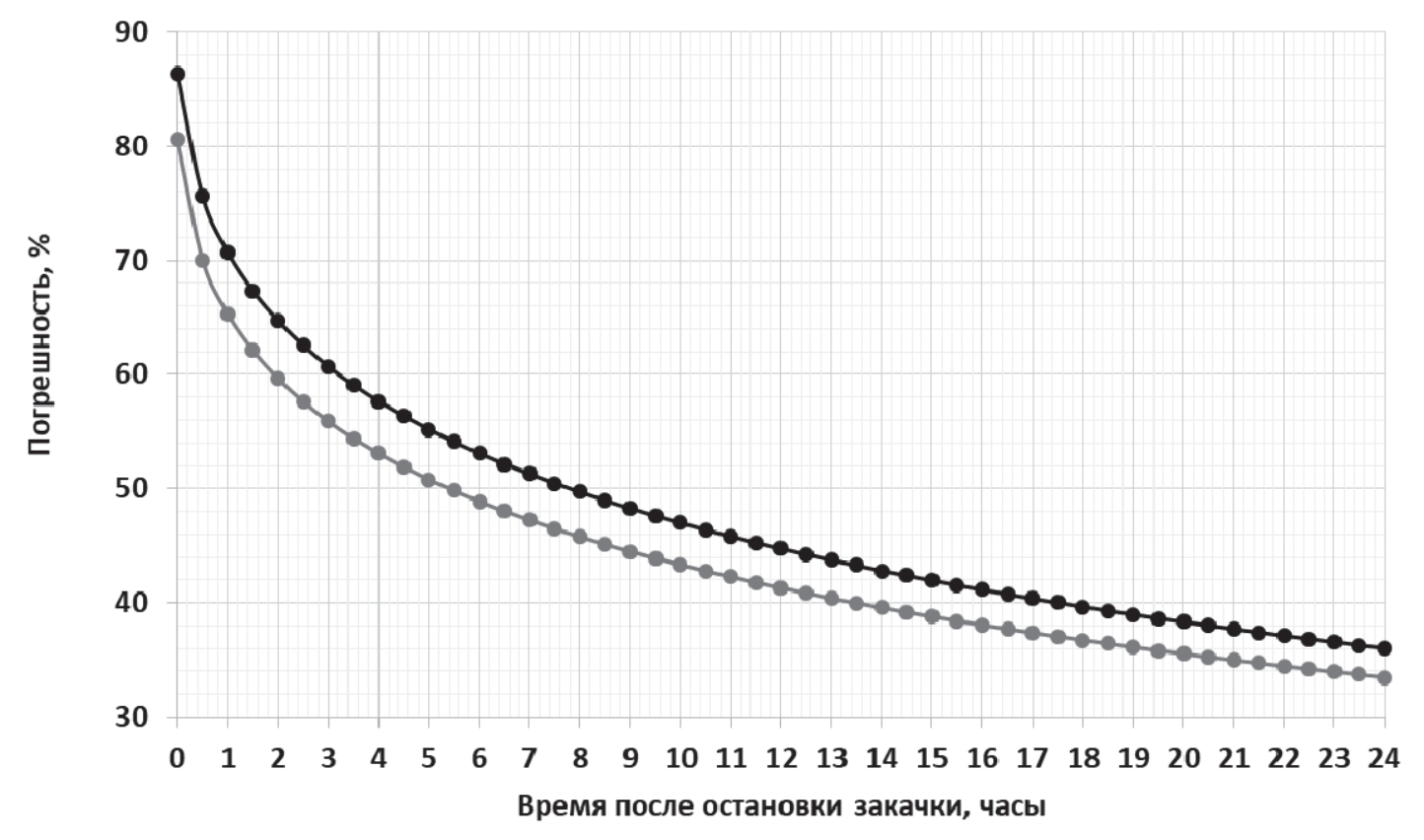

$\rightarrow 5: 5 \rightarrow 10: 10$

Рис. 12. Изленение погрешности в зависилости от врелени для доли непроницаемых пропластков $90 \%$

Fig. 12. Change of deviation depending on the time for the proportion of impervious layers of $90 \%$

\section{СПИСОК ЛИТЕРАТУРЫ}

1. Determining Multilayer Formation Properties from Transient Temperature and Pressure Measurements / W. Sui, D. Zhu, A.D. Hill, C.A. Ehlig-Economides // Paper SPE 116270. - Denver, Colorado, USA, 21-24 September 2008. - P. 387-404.

2. Mao Y., Zeidouni M. Temperature Transient Analysis for Characterization of Multylayer Reservoirs with Crossflow // Paper SPE 185654. SPE Western Regional Meeting held in Bakersfield. California, USA, 23 April 2017. - P. 114-134.

3. Park H. Well Test Analysis of a multilayered reservoir with formation crossflow. PhD. - Stanford, 1989. 164 p.

4. Чекалюк Э.Б. Термодинамика нефтяного пласта. - М.: Недра, 1965. $-238 \mathrm{c}$.

5. Thermal Modeling for Characterization of Near Wellbore Zone and Zonal Allocation / A.Sh. Ramazanov, R.A. Valiullin, A.A. Sadretdinov, V.V. Shako, V.P. Pimenov, V.N. Fedorov, K.V. Belov // Paper SPE 136256. Russia Oil \& Gas Technical Conference and Exhibition. - Moscow, Russia, 26-28 0ctober 2010. - P. 739-760.

6. Onur M., Cinar M. Temperature Transient Analysis of Slightly Compressible, Single-Phase Reservoirs // Paper SPE 180074. SPE ATCE. - Vienna, Austria, 30 May - 2 June 2016. P. 1309-1356.

7. Onur M., Cinar M. Interpretation and Analysis of Transient Sandface and Wellbore Temperature Data // Paper SPE 181710. SPE ATCE. - Dubai, UAE, 26-28 September 2016. - P. 121-167.

8. The Use of Simulators for Designing and Interpretation of Well Thermal Survey / A. Ramazanov, R. Valiullin, R. Sharafutdinov, T. Khabirov, A. Sadretdinov, M. Zakirov, D. Islamov // Understanding the Harmony of the Earth's Resources through Integration of Geosciences: Abstract Book of $7^{\text {th }}$ Saint Petersburg International Conferences \& Exhibition. - Saint Petersburg, Russia, 11-14 April, 2016. - 4 p.

9. Duru 0., Horne R.N. Combined Temperature and Pressure Data Interpretation: Applications to Characterization of Near-Wellbo- re Reservoir Structures // Paper SPE 146614. SPE ATCE. - Denver, Colorado, USA, 30 October - 2 November 2011. - P. 98-116.

10. Gajdukov L.A., Posvyanskij D.V., Novikov A.V. Investigation of Thermodynamic Processes during Multiphase Fluid Filtration to the Well with Perforation Channels in Damage Reservoir for Determination of Near Wellbore Zone Properties // Paper SPE 181964. Russian Oil and Gas Technical Conference and Exhibition SPE. - Moscow, Russia, 26 0ctober 2016. - P. 35-51.

11. Похотников С.П., Елисеенков В.В. Гидродинамические расчеты слоистых пластов на основе модифицированных относительных проницаемостей // Прикладная механика и техническая физика. - 2001. - № 5. - С. 115-121.

12. Ахмедов А.С., Ахмедова 3.Х., Ахмедова Х.Г. Влияние слоистой неоднородности пласта на показатели разработки при неизотермическом вытеснении парафинистой нефти водой // Вестник Астраханского государственного технического университета. - 2016. - № 1. - С. 14-21.

13. Исследование восстановления температуры в скважине после прекращения закачки воды в пласт с трещиной ГРП / А.М. Шарипов, Р.Ф. Шарафутдинов, А.Ш. Рамазанов, Р.А. Валиуллин // Вестник Башкирского университета. 2017. - № 2. - С. 315-319.

14. Исламов Д.Ф., Рамазанов А.Ш. Моделирование переходных температурных процессов в пласте при отборе и закачке жидкости // Вестник академии наук республики Башкортостан. 2017. - T. 24. - № 3. - С. 84-91.

15. Исламов Д.Ф., Садретдинов А.А. Определение параметров околоскважинной зоны по нестационарным температурным измерениям в скважине // Известия высших учебных заведений. Нефть и газ. -2017 . - № 5. - С. 15-19.

16. Исламов Д.Ф., Рамазанов А.Ш. Нестационарное температурное поле при фильтрации жидкости в неоднородном пласте // Вестник Башкирского университета. - 2016. - № 1. - С. 4-8.

17. Рамазанов А.Ш., Нагимов В.М. Аналитическая модель для расчета температурного поля в нефтяном пласте при нестацио- 
нарном притоке жидкости // Электронный научный журнал «Нефтегазовое дело». - 2007. - № 1. URL: http://ogbus.ru/authors/Ramazanov/Ramazanov_2.pdf (дата обращения: 19.03.2017).

18. Рамазанов А.Ш., Нагимов В.М., Ахметов Р.К. Температурное поле в пласте с учетом термодинамических эффектов при работе скважины с переменным дебитом // Электронный научный журнал «Нефтегазовое дело». - 2013. - № 1. URL: http://ogbus.ru/authors/Ramazanov/Ramazanov_4.pdf (дата обращения: 19.03.2017).
19. Рамазанов А.Ш., Филиппов А.И. Температурные поля при нестационарной фильтрации жидкости // Изв. АН СССР. Механика жидкости и газа. - 1983. - № 4. - С. 175-178.

20. Басниев К.С., Кочина И.Н., Максимов В.М. Подземная гидромеханика. - М.: Недра, 1993. - 416 с.

21. Карслоу Г., Егер Д. Теплопроводность твердых тел. - М.: Наука, 1964. -488 с.

Информация об авторах

Ислалов Д.Ф., ассистент кафедры геофизики Башкирского государственного университета.

Caдретдинов A.A., кандидат физико-математических наук, ассистент кафедры геофизики Башкирского государственного университета. 
UDC 550.3:536.2

\title{
ANALYSIS OF TEMPERATURE FIELD IN LAYERED RESERVOIR
}

\author{
Denis F. Islamov',
}

islamovden@rambler.ru

\author{
Alexander A. Sadretdinov', \\ islamovden@rambler.ru

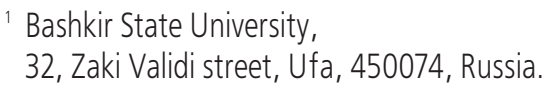

The relevance of the research. At present time the interest in quantitative interpretation of temperature surveys is growing. Individual flow rate and reservoir pressure of each layer, behind-casing flow rate, hydrodynamic layer parameters, characterization of permeability changing at near-wellbore zone become the purposes of quantitative interpretation. Non-stationary temperature and pressure in the well are used as input data for transient processes analysis, and temperature logs are used for quasi-stationary analysis. Determination of individual layer flow rates and near-wellbore zone parameters are of particular interest.

The main aim of the research is to assess the degree of affect of reservoir uniformity assumption on the observed temperature for some scenarios of well operation.

The methods. A numerical model is developed and investigated, discretization is carried out by the method of control volumes, the method of variable directions is used. The correctness of the numerical solution is verified by comparison with the known analytical solutions.

The results. The authors have studied the problem of a nonstationary temperature field in a layered reservoir. The average deviation of the solution for the case of injection can reach $20 \%$ or more, the value depends on the thickness (total) of the reservoir. The average deviation of the solution for the case of injection reaches a maximum of 6-10 hours and then slowly decreases over time. In the case of production, the deviation value can reach $100 \%$, the maximum is reached at the beginning of recovery. Further, the deviation decreases, reaching after 24 hours the value of the order of $40 \%$ of the initial deviation. Setting the permissible error of the solution in $10 \%$ at modeling recovery in layered reservoirs it is necessary to take into account the stratification at its values above 15-25\%, depending on the scenario of work the well.

\section{Key words:}

Geophysics, thermal logging, well, reservoir, permeability, numerical solution.

The research was financially supported by the RFBR (project no.16-35-00275 мол_a, project no.16-29-15130 opu_м).

\section{REFERENCES}

1. Sui W., Zhu D., Hill A.D., Ehlig-Economides C.A. Determining Multilayer Formation Properties from Transient Temperature and Pressure Measurements. Paper SPE 116270 presented at the SPE ATCE. Denver, Colorado, USA, 21-24 September 2008. pp. $387-404$.

2. Mao Y., Zeidouni M. Temperature Transient Analysis for Characterization of Multylayer Reservoirs with Crossflow. Paper SPE 185654. SPE Western Regional Meeting held in Bakersfield. California, USA, 23 April 2017. pp. 114-134.

3. Park H. Well Test Analysis of a multilayered reservoir with formation crossflow. PhD. Stanford, 1989. 164 p.

4. Chekalyuk E.B. Termodinamika neftyanogo plasta [Thermodynamics of oil reservoir]. Moscow, Nedra Publ., 1965. 238 p.

5. Ramazanov A.Sh., Valiullin R.A., Sadretdinov A.A., Shako V.V., Pimenov V.P., Fedorov V.N., Belov K.V. Thermal Modeling for Characterization of Near Wellbore Zone and Zonal Allocation. Paper SPE 136256 presented at the SPE Russia Oil \& Gas Technical Conference and Exhibition. Moscow, Russia, 26-28 October 2010. pp. 739-760.

6. Onur M., Cinar M. Temperature Transient Analysis of Slightly Compressible, Single-Phase Reservoirs. Paper SPE 180074 presented at the SPE ATCE. Vienna, Austria, 30 May - 2 June 2016. pp. 1309-1356.

7. Onur M., Cinar M. Interpretation and Analysis of Transient Sandface and Wellbore Temperature Data. Paper SPE 181710 presented at the SPE ATCE. Dubai, UAE, 26-28 September 2016. pp. 121-167.

8. Ramazanov A., Valiullin R., Sharafutdinov R., Khabirov T., Sadretdinov A., Zakirov M., Islamov D. The Use of Simulators for
Designing and Interpretation of Well Thermal Survey. Abstract Book of $7^{\text {th }}$ Saint Petersburg International Conferences \& Exhibition. Understanding the Harmony of the Earth's Resources through Integration of Geosciences. Saint Petersburg, Russia, 11-14 April, 2016. 4 p.

9. Duru 0., Horne R.N. Combined Temperature and Pressure Data Interpretation: Applications to Characterization of Near-Wellbore Reservoir Structures. Paper SPE 146614 presented at the SPE ATCE. Denver, Colorado, USA, 30 October - 2 November 2011. pp. 98-116.

10. Gajdukov L.A., Posvyanskij D.V., Novikov A.V. Investigation of Thermodynamic Processes During Multiphase Fluid Filtration to the Well with Perforation Channels in Damage Reservoir for Determination of Near Wellbore Zone Properties. Paper SPE 181964 presented at the Russian Oil and Gas Technical Conference and Exhibition SPE. Moscow, Russia, 26 October 2016. pp. 35-51.

11. Pokhotnikov S.P., Eliseenkov V.V. Hydrodynamic calculations of layered seams based on modified relative permeabilities. Prikladnaya mekhanika $i$ tekhnicheskaya fizika, 2001, no. 5, pp. 115-121. In Rus.

12. Akhmedov A.S., Akhmedova Z.Kh., Akhmedova Kh.G. Influence of layered heterogeneity of the formation on the development indices when the paraffinic oil is not isothermally displaced by water. Vestnik Astrahanskogo gosudarstvennogo tekhnicheskogo universiteta, 2016, no. 1, pp. 14-21. In Rus.

13. Sharipov A.M., Sharafutdinov R.F., Ramazanov A.Sh., Valiullin R.A. Study of the temperature recovery process in a well after stop of water injection in a reservoir with hydraulic fracturing. Vestnik Bashkirskogo universiteta, 2017, no. 2, pp. 315-319. In Rus. 
14. Islamov D.F., Ramazanov A.Sh. Simulation of transient temperature processes in oil reservoirs at fluid withdrawal and injection. Vestnik akademii nauk respubliki Bashkortostan, 2017, no. 3, pp. 84-91. In Rus.

15. Islamov D.F., Sadretdinov A.A. Determination of near wellbore zone properties from non-stationary temperature measurements. Izvestiya vysshikh uchebnykh zavedeniy. Neft $i$ gaz, 2017, no. 5, pp. 15-19. In Rus.

16. Islamov D.F., Ramazanov A.Sh. Non-stationary temperature field for fluid flow in heterogeneous reservoir. Bullet of Bashkir University, 2016, no. 1, pp. 4-8. In Rus.

17. Ramazanov A.Sh., Nagimov V.M. Analytical Model for Calculating Temperature Distribution in Oil Reservoir during Unsteady Fluid Inflow. Elektronny nauchny zhurnal «Neftegazovoe delo», 2007, no. 1. Available at: http://ogbus.ru/authors/Ramazanov/Ramazanov_2.pdf (accessed 19 March 2017).

\section{Information about the authors}

Denis F. Islamov, assistant, Bashkir State University.
18. Ramazanov A.Sh., Nagimov V.M., Akhmetov R.K. Temperature field in the reservoir considering thermodynamic effects of the well at its variable production operation. Elektronny nauchny zhurnal "Neftegazovoe delo», 2013, no. 1. Available at: http://ogbus.ru/authors/Ramazanov/Ramazanov_2.pdf (accessed 19 March 2017).

19. Ramazanov A.Sh., Filippov A.I. Temperature field in non-stationary filtration. Izvestiya AN SSSR. Mekhanika Zhidkosti i Gaza, 1983, no. 4, pp. 175-178. In Rus.

20. Basniev K.S., Kochina I.N., Maksimov V.M. Podzemnaya gidromekhanika [Underground Fluid Mechanics]. Moscow, Nedra Publ., 1993. $416 \mathrm{p}$.

21. Carslou H., Jaeger D. Teploprovodnost tverdykh tel [Thermal conductivity of solids]. Moscow, Nauka Publ., 1964. 488 p.

Received: 2 October 2018.

Alexander A. Sadretdinov, Cand. Sc., assistant, Bashkir State University. 